Utah State University

DigitalCommons@USU

1978

\title{
Biomass and nutrient distribution in aspen, pine, and spruce stands on the same soil type in Minnesota
}

David H. Alban

Donald A. Perala

Bryce E. Schlaegel

Follow this and additional works at: https://digitalcommons.usu.edu/aspen_bib

Part of the Forest Sciences Commons

\section{Recommended Citation}

Alban, David H.; Perala, Donald A.; Schlaegel, Bryce E. Biomass and nutrient distribution in aspen, pine, and spruce stands on the same soil type in Minnesota. Canadian Journal of Forest Research. 8(3):

290-299.

This Article is brought to you for free and open access by the Aspen Research at DigitalCommons@USU. It has been accepted for inclusion in Aspen Bibliography by an authorized administrator of DigitalCommons@USU. For more information, please contact

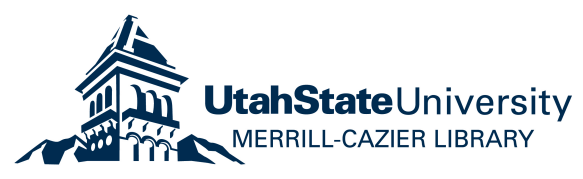




\title{
Biomass and nutrient distribution in aspen, pine, and spruce stands on the same soil type in Minnesota
}

\author{
. \\ David H. Alban, Donald A. Perala, and Bryce E. Schlaegel 1 \\ U.S. Department of Agriculture, Forest Service, North Central Forest Experiment Station, \\ Grand Rapids, MN, U.S.A. 55744 \\ Received August 22, 19772 \\ Accepted May 10, 1978
}

\begin{abstract}
Alban, D. H., D. A. Perula and B. E Schlaeget. 1978. Biomass and nutrient distribution in aspen, pine, and spruce stands on the same soil type in Minnesota. Can. J. For. Res. 8: 290-299.

Vegetation and soils were sampled in adjacent 40 year-old stands of red pine (Pinus resinosa Ait.), jack pine (Pinus banksiana Lamb.), white spruce (Picea glauca (Moench.) Voss), and aspen (Populus tremuloides Michx, $P$. grondidentata Michx.) on a very fine sandy loam soil in north-central Minnesota. Total trefbiomass was greatest for red pine followed by aspea, spruce, and jack pine. Nutrient weights $(\mathrm{N}, \mathrm{P}, \mathrm{K}, \mathrm{Ca}, \mathrm{Mg})$ in the trees were greatest in aspen followed generally by spruce, red pine, and jack pine. Particulariy large proportions of biomass and nutrients were found in aspen bark and spruce foliage and branches. Understory biomass contributed less than $1.2 \%$ of the total organic matter in the vegetation-soil complex but contributed up to $5.0 \%$ of the nutrients. Exchangeable $\mathrm{Ca}$ in the surface soil was much lower under aspen and spruce than under the pines. No significant soil differences between species were detected below $36 \mathrm{~cm}$. Harvesting the entire aboveground portion of the tree would remove up to three times more nutrients from the site than would harvesting only the bole.
\end{abstract}

Alban, D. H., D. A. Perala et B. E Schlaeger. 1978. Biomass and nutrient distribution in aspen, pine, and spruce stands on the same soil type in Minnesota. Can. J. For. Res. 8: 290-299.

Les auteurs ont échantillonné la végétation et les sols de peuplements adjacents de 40 ans de pin rouge (Pinus resinosa Ait), de pin gris (Pinus banksiana Lamb.), d'épicéa (Picea glauca (Moench.) Voss), et de penplier (Populus tremuloides Michx. et P. grandidentata Michx.) sur loam sableux très fin dans la partie nord-centraje du Minnesota. La biomasse totaie des arbres était la plus élevée chea le pin rouge, suivi du peuplier, de l'épicéa et du pin gris. La masse d'eléments nutritits $(N, P, K, C a, M g)$ dans les arbres était la plus élevée chez le peuplier, saivi généralement de l'Épicéa, du pin rouge et du pin gris. Des proportions particulièrement importantes de la biomasse et des élémeats nutritifs ont été observées dans l'écorce du peuplier et les feuilles tt les branches de l'épicéa. La biomasse de la sous-végétation contribuait moins de $1.2 \%$ de la matière organique totale dans le complexe sol-végétation, mais jusqu'à $5.0 \%$ des éléments nutritifs. Le calcium échangeable de la mrface du sol était beaucoup plus faibie sous le peuplier et l'épicéa que sous les pins. Aucune différence significative dans le sol au-delà de $36 \mathrm{~cm}$ ne fut décelée entre les espéces. La récolte de toute la partie aérienne des arbres ealèverait jusqu'à trois fois plus d'éléments nutritifis de la station que l'exploitation des seules tiges.

[Traduit par le journal]

Increasing wood and fiber yields are major goals of modern forestry. Yields can be increased by thinning, fertilizing, selecting genetically superior stock, matching the proper species to the site, and utilizing the entire tree. All of these practices may influence the site itself. Increasing the yield of a given species will increase the nutrient drain from the site, which may alter the site's productivity.

'Present address: Southern Forest Experiment Station, Stoneville, MS, U.S.A.

'First revision received December 15, 1977, second revision received April 6, 1978.
In order to quantify potential nutrient drain from timber harvesting we examined the biomass and nutrient distribution within four forest types on the same soil in Minnesota.

In this paper total tree refers to the entire tree including roots, and aboveground tree refers to that portion of the tree above a $15 \mathrm{~cm}$ stump.

\section{Study Area}

The study area is located in north-central Minnesota, U.S.A., on the Pike Bay Experimental Forest $\left(47^{\circ} 20^{\prime} \mathrm{N}, 94^{\circ} 30^{\prime} \mathrm{W}\right)$. The climate is continental, 
TABLE 1. Stand characteristics

\begin{tabular}{|c|c|c|c|c|c|c|}
\hline Stand & $\begin{array}{c}\text { No. } \\
\text { trees } \\
\text { per } \\
\text { hectare }\end{array}$ & $\begin{array}{c}\text { Mean } \\
\text { beight, } \\
\text { m }\end{array}$ & $\begin{array}{c}\text { Mean dbh } \\
\text { (outside } \\
\text { bark) } \\
\mathrm{cm}\end{array}$ & $\begin{array}{c}\text { Basal } \\
\text { area, } \\
\mathrm{m}^{2} / \mathrm{ba}\end{array}$ & $\begin{array}{l}\text { Yolume } \\
\text { inside } \\
\text { bark, } \\
\mathrm{m}^{3} / \mathrm{ha}\end{array}$ & $\begin{array}{c}\text { Site } \\
\text { index } \\
\text { (50 years), } \\
\mathrm{m}\end{array}$ \\
\hline \multicolumn{7}{|l|}{ Aspen } \\
\hline $\begin{array}{l}\text { Aspen } \\
\text { Otber species } \\
\text { White spruce } \\
\text { Red pine } \\
\text { Jack pine }\end{array}$ & $\begin{array}{l}1334 \\
1655 \\
2187 \\
1780 \\
1580\end{array}$ & $\begin{array}{l}20.3 \\
11.0 \\
14.4 \\
17.6 \\
18.4\end{array}$ & $\begin{array}{r}18 \\
7 \\
15 \\
19 \\
17\end{array}$ & $\begin{array}{r}34.7 \\
7.0 \\
41.1 \\
51.9 \\
35.1\end{array}$ & $\begin{array}{r}286 \\
39 \\
256 \\
408 \\
263\end{array}$ & $\begin{array}{l}22.9 \\
18.3 \\
20.7 \\
21.3\end{array}$ \\
\hline
\end{tabular}

meaning cold winters (mean January temperature $-14^{\circ} \mathrm{C}$ ), cool summers (mean July temperature $20^{\circ} \mathrm{C}$ ), and $61 \mathrm{~cm}$ of precipitation (balf falls during the growing season).

The soil has developed from calcareous glacial till and is classified as Warba very fine sandy loam (Typic Eutroboralf, Soil Survey Staff 1975); it is well drained and moderately acid ( $\mathrm{pH} 5-6$ ) above the $C$ horizon. The soil occurs on a gently undulating till plain and is morphologically uniform for the entire study area. A generalized soil description follows.

\begin{tabular}{|c|c|c|}
\hline 01 & $3-1.5 \mathrm{~cm}$ & recognizable remains of \\
\hline $\mathrm{O} 2$ & $1.5-0 \mathrm{~cm}$ & $\begin{array}{l}\text { foliage, twigs, cones, etc. } \\
\text { well-decomposed organic } \\
\end{array}$ \\
\hline A21 & $0-5 \mathrm{~cm}$ & $\begin{array}{l}\text { dark gray very fine sandy } \\
\text { loam, roots abundant }\end{array}$ \\
\hline A22 & $5-36 \mathrm{~cm}$ & $\begin{array}{l}\text { gray-brown loamy very } \\
\text { fine sand, roots common }\end{array}$ \\
\hline A\&B & $36-61 \mathrm{~cm}$ & $\begin{array}{l}\text { mixed borizon that has } \\
\text { ebaracteristics of horizons } \\
\text { above and below, very few } \\
\text { roots }\end{array}$ \\
\hline B2 & $61-70 \mathrm{~cm}$ & $\begin{array}{l}\text { dark brown clay loam with } \\
\text { blocky structure }\end{array}$ \\
\hline $\begin{array}{r}\mathrm{B3} \\
\mathrm{C}\end{array}$ & $\begin{array}{r}70-104 \mathrm{~cm} \\
104-170+\mathrm{cm}\end{array}$ & $\begin{array}{l}\text { brown loam } \\
\text { olive brown loam, } \\
\text { calcareous }\end{array}$ \\
\hline
\end{tabular}

The vegetation, if undisturbed, proceeds to maple (Acer saccharum Marsh.) - basswood (Tilia americana L.) (Kittredge 1934). Common strubs and herbs presently include downy arrowwood (Viburnum Rafinesquianum Schult.), choke cherry (Prunus virginiana L.), hazel (Corylus cornuta Marsh., C. americana Walt.), dogwood (Cornus rugosa Lam., C. stolonifera Michx., C. alternifolia L.), false Solomon's seal (Smilacina racemosa (L.) Desf.), twisted stalk (Streptopus roseus Michx.), wild lily-of-the-valley (Maianthemum canadense Desf.), early-meadowrue (Thalictrum dioicum L.), large leaf aster (Aster macrophyllus L.), sedges (Carex sp.).
The area was harvested for white pine (Pinus strobus L.) before 1923, for aspen (Populus tremuloides Michx., P. grandidentata Michx.) and mixed hardwoods in 1929-1930, and for firewood in 1932-1933. In the spring of 1933 about 8 ha were cleared of remaining trees and 0.4 ha adjoining plantations were established with red pine (Pinus resinosa Ait.), jack pine (Pinus banksiana Lamb.), or white spruce (Picea glauca (Moench.) Voss). An unplanted control area developed through suckering into a fully stocked aspen stand. The conifer stock (mostly 2-0) was planted in scalped areas at spacings of $1 \times 1.5 \mathrm{~m}$ and the conifer plantations were weeded as necessary for the first few years. The current study includes two 0.4 ha plantations each of red pine and white spruce and one 0.4 ha plantation each of aspen and jack pine. The conifer stands are neariy pure but the aspen stand contains a number of trees other than aspen (primarily Acer saccharum, A. rubrum L., and Fraxinus pennsylvanica Marsh.). However, these hardwoods are in the lower crown classes and thus their basal area and volume is small (Table 1). The site index values are about average for aspen and spruce in Minnesota and good for red and jack pine. Bole wood weights and volumes of these stands have been reported previously (Schlaegel 1975).

All four species are of the age and size at which a commercial bole harvesting operation for purpwood would normally be undertaken. If red pine and white spruce are grown for saw logs, the stands are slightly past the age at which the first commercial thinnings might be begun.

\section{Methods}

\section{Overstony}

Overstory is defined here as all trees more than $3.8 \mathrm{~cm}$ diameter at breast height (dbh). Ten $80-\mathrm{m}^{2}$ plots were established in each of the 0.4 ha plots in the spring of 1973 after 40 years of growth. On each plot the dbb of every overstory tree was measured. Ten trees of each species were relected for destructive sampling (one tree per plot chosen randomly with the restriction that they represent the com- 
CAN. J. FOR, RES. VOL. 8, 1978

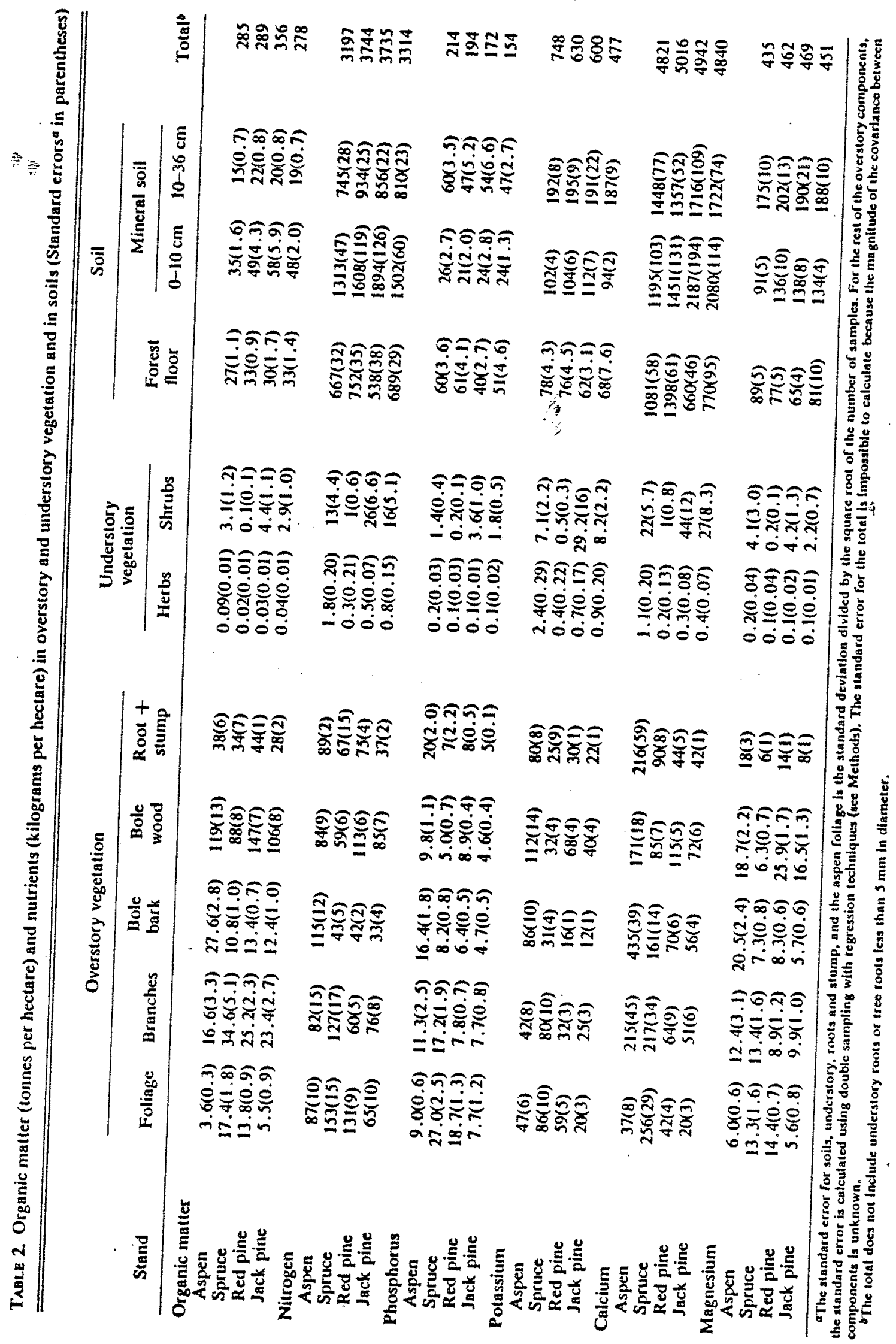


plete range of diameter classes). The sample tree was felled (15-cm stump), total height measured, and the stem sectioned into $1.2-\mathrm{m}$ bolts that were weighed green in the field. Also all the limbs on each bolt were removed and weighed green. A 3-cm-thick disc and a randomly selected branch from each bolt were placed in plastic bags and transported to the laboratory the same day.

In the laboratory the bark was separated from the wood of each disceand the green weight of each component measured: The samples were then oven-dried at $100^{\circ} \mathrm{C}$ for $48 \mathrm{~b}$ and reweighed. The moisture content and bark:wood ratio were used to calculate the ovendry weight of the bole bark and bole wood from the green weight of each bolt as measured in the field. Tree weights of bole wood and bole bark are the sum values calculated for each bolt

The branch samples were weighed green in the laboratory, oven-dried at $70^{\circ} \mathrm{C}$, defoliated by hand, and redried. The moisture content and foliage:branch ratio were used to calculate the ovendry weight of foliage and branches from the field-measured green branch weight.

Based on the 10 sample trees per species, regression equations were developed to relate weight of nutrients or ovendry biomass (by tree aboveground components) to tree diameter and height. The form of the equations was

$$
\ln (\text { weight })=a+b\left(\ln \left(D^{2} H\right)\right)
$$

where $D$ is the tree diameter at breast height in centimetres, and $\hat{H}$ is estimated tree height (metres) calculated from a height-diameter equation developed from the 10 sample trees per species. There were 24 equations per species: four components (foliage, branches, bole bark, and bole wood), ovendry weights, and five nutrients ( N, $P, K$ $\mathrm{Ca}$, and $\mathrm{Mg}$ ). The equations were corrected for the in-in bias (Baskerville 1972) and generally bad $R^{2}$ values greater than 0.90 and standard errors of the mean less than $10 \%$. The equations were solved for every tree that had been measured for diameter and that had been estimated for height from the height-diameter equation. The average tree weight of nutrients or biomass (by tree component) was calculated and multiplied by the number of trees per hectare to obtain weights on an area basis.

The variance of these estimates takes into account the variances for the in-in equation, the beight-diameter equation, and the number of trees per hectare. The square root of the variance gives the standard error (Tabie 2). The program for calculating the variance is a modified version ${ }^{3}$ of double samping with regression (Cochran
1963 ).

For each species two additional trees of mean bole volume were felled in August 1974 and all roots greater than $5 \mathrm{~mm}$ were hand excayated. The entire root system (plus the $15 \mathrm{~cm}$ stump) was washed lightly with distilled water to remove soil particies, oven-dried $\left(70^{\circ} \mathrm{C}\right)$, and weighed.

Because aspen foliage was not present when the 10 trees were sampled for aboveground biomass, all foliage of the two aspen root sample trees was removed by band, oveadried $\left(70^{\circ} \mathrm{C}\right)$, and weighed. Although our aspen foliage sample is small, the foliage weights agree with literature values. We found aspen foliage to be $2.2 \%$ of the total aboveground tree weight, which is comparable with the values of $2.2,1.6$, and $2.4 \%$ reported for mature aspen in

\footnotetext{
"Margaret Martin. Variances in some biomass tudie utilizing doubie sampling. Manuscript in preparation.
}

Alberta, Ontario, and Wisconsin (Peterson et al. 1970; Pollard 1972; Zavitkovski 1971).

\section{Understory}

In early September 1972 , ten $4 \mathrm{~m}^{2}$ circular plots were systematically located in each forest type. All live vegetation less than $3.8 \mathrm{~cm}$ dbh was clipped at groundline and separated into the shrub layer (shrubs, vines, and bardwood seedlings and saplings) and the herbaceous layer. The sarub layer was weighed in the field, and a subsample of representative stems per plot was bagged for dry weight $\left(70^{\circ} \mathrm{C}\right)$ and nutrient determinations in the laboratory. All herbaceous vegetation was bagged for these same determinations. The fresh and ovendry shrub layer subsample weight ratio was used to determine plot dry weight from the plot fresh weight. The entire berbaceous layer sample was dried $\left(70^{\circ} \mathrm{C}\right)$ and weighed. Roots of understory species were not sampled.

\section{Soils}

On each 0.4ha area (two of red pine and white spruce, and one each of aspen and jack pine) twenty $930-\mathrm{cm}^{2}$ samples of the forest floor were collected and composited into five samples per plot. Directly beneath each forest floor sample location mineral soil samples were removed from the following depths: $0-10,10-25,25-36$, and 36 $61 \mathrm{~cm}$. The mineral soil samples were also composited into five final samples for analysis per plot. In addition, two deep pits were dug under each species. In each pit the soil profile was described and horizon samples were collected to a depth of about $2 \mathrm{~m}$.

\section{Chemical Analysis}

Samples of tree components, strub and herb layers, and the forest floor were ground to pass a 20 -mesh screen. Nitrogen in all samples was determined by the macro. Kjeldahl method (Bremner 1965). Tree components were dry ashed $\left(300^{\circ} \mathrm{C}\right.$ ) and $\mathrm{P}, \mathrm{Ca}, \mathrm{Mg}$, and $\mathrm{K}$ determined by emission spectroscopy. Understory plants and forest fioor samples were dry ashed and analyzed for $\mathrm{Ca}, \mathrm{Mg}$, and $\mathrm{K}$ by atomic absorption and for $\mathrm{P}$ by the molybdophosphoric biue colorimetric method (Jackson 1958).

Mineral soil samples were air dried and passed through a $2-\mathrm{mm}$ screen. The material greater than $2 \mathrm{~mm}$ was weighed and discarded. Mineral soil $\mathrm{Ca}, \mathrm{Mg}$, and $\mathrm{K}$ were extracted with $1 \mathrm{~N}$ NH.OAC and determined by atomic absorption; $P$ was extracted with $0.002 \mathrm{NH} \mathrm{SO}_{4}$ and determined by the molybdophosphoric blue colorimetric method. Organic matter in the mineral soil is the total carbon (C) content (by induction furnace, Allison et al. 1965) multiplied by the conversion factor of 1.7 (Broadbent 1965). Organic matter in the forest foor is the total ovendry weight minus the ash content.

\section{Results}

The trees contained two-thirds to three-fourths of the total measured organic matter (Fig. 1). The biomass in these stands is similar to that of comparable stands of Pinus and Picea in the temperate forest zone (Art and Marks 1971; Ovington 1962) and to aspen in Minnesota (Bray and Dudkiewica 1963) and Wisconsin (Boyle and Ek 1972). Total tree biomass is greatest for red pine followed by 
CAN. J. FOR. RES. VOL. 8, 1978

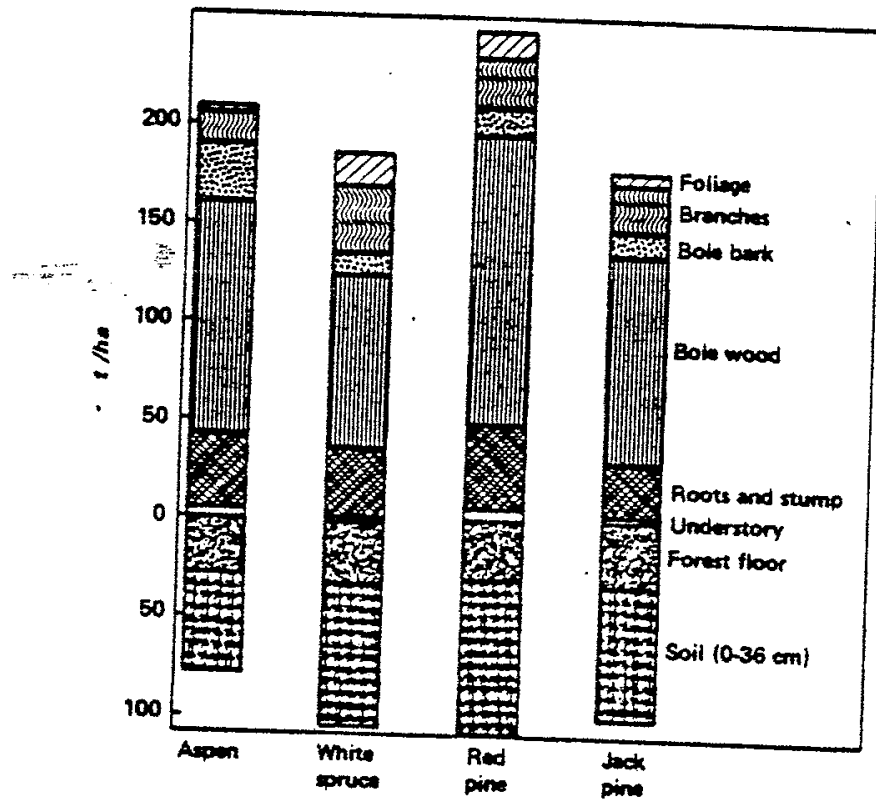

Fro. 1. Organic matter distribution.

aspen, spruce, and jack pine. Bole wood and root biomass follow similar species trends (Table 2). Branch and foliage weights are greatest for spruce whereas bole bark weight is greater for aspen than for any other species. The understory contributes little to total biomass in these dense stands. Organic matter in the soil is lowest under aspen. Similar comparisons (but with different species) in England also showed spruce canopy biomass to be greater than other species, and showed that conifer stands generally have greater biomass than hardwoods of the same age (Ovington 1956).

In contrast to organic matter, which is concentrated in the living vegetation, the nutrients are concentrated in the soil (Fig. 2). Oniy $6-23 \%$ of the $\mathrm{N}, \mathrm{Ca}$, and $\mathrm{Mg}$ and only $21-50 \%$ of the $\mathrm{P}$ and $K$ is found in the vegetation. The shrub and herb layers, because of their high nutrient concentrations, comprise a larger part of the nutrient pool than the organic matter pool. But even so the understory contains at most only a small percentage of each
nutrient.

The species differed greatly in nutrient contents. Aspen contained the greatest amount of each nutrient and jack pine contained the least (Fig. 2). In spite of having the largest biomass per hectare, red pine generally had lower amounts of nutrients than either aspen or white spruce, which reflects the low nutrient concentration in red pine tissues. Not only does the total amount of nutrient differ between species but its distribution among components differs also. Spruce contains a higher proportion of total tree nutrients in the branches and foliage than other species, whereas aspen contains a higher proportion in the bark. These trends are similar to those for biomass but accentuated because of the high nutrient concentrations found in aspen bark and spruce foliage and branches. Approximately half of the aboveground tree nutrients are in the bole; about half is in the wood and the other half in the bark. So only about a fourth of the nutrients in the aboveground tree are in the bole wood.

Soil organic matter and nutrients are concentrated in the forest floor and the surface $10 \mathrm{~cm}$ of mineral soil. Soil properties that differed significantly between the tree species were organic matter, $N$, and $\mathrm{Ca}$. Differences were greatest in the forest floor and the $0-10 \mathrm{~cm}$ mineral soil layer, and decreased rapidly with depth. In the $25-36 \mathrm{~cm}$ layer few differences due to species were significant, and below $36 \mathrm{~cm}$ no significant differences occurred. This substantiates the assumption that the soils didinot differ
significantly when the forests were established.

\section{Discussion}

If these stands were harvested, more nutrients would be removed from the aspen and spruce sites than from the pines, and about twice as much of the nutrients would be removed if the entire aboveground tree were taken than if only the boles were removed (Table 2). The nutrients removed in such logging of the aspen stand would be about twice as great as reported from a Wisconsin aspen stand of similar age and biomass harvested commercially (diameter limit $12.7 \mathrm{~cm}$ ) during leaf off time (Boyle and Ek 1972). Nutrient removal by aboveground tree harvesting of the jack pine, red pine, and white spruce stands would be somewhat greater than for jack pine in Ontario (Morrison 1973), red pine in New York (Jurgensen and Leaf 1965; Madgwick et al. 1970) or spruce-fir in Quebec (Weetman and Webber 1972), all of which are growirg on poorer sites than those of this study.

The impact of these nutrient removals on the productivity of the site can be known for certain only by measuring the growth of subsequent stands. Several cases have been reported where nutrient removal from forest land has reduced the growth of succeeding trees (Lutz and Chandler 1946). Past agricultural use of sandy soils in eastern North America resulted in poor growth of subsequently planted red pine, which could be corrected by $\mathrm{K}$ fertilization (Leaf et al. 1975; Wittwer et al. 1975). On infertile soils in Europe where a high percentage of the total nutrients are contained in the vegetation, 


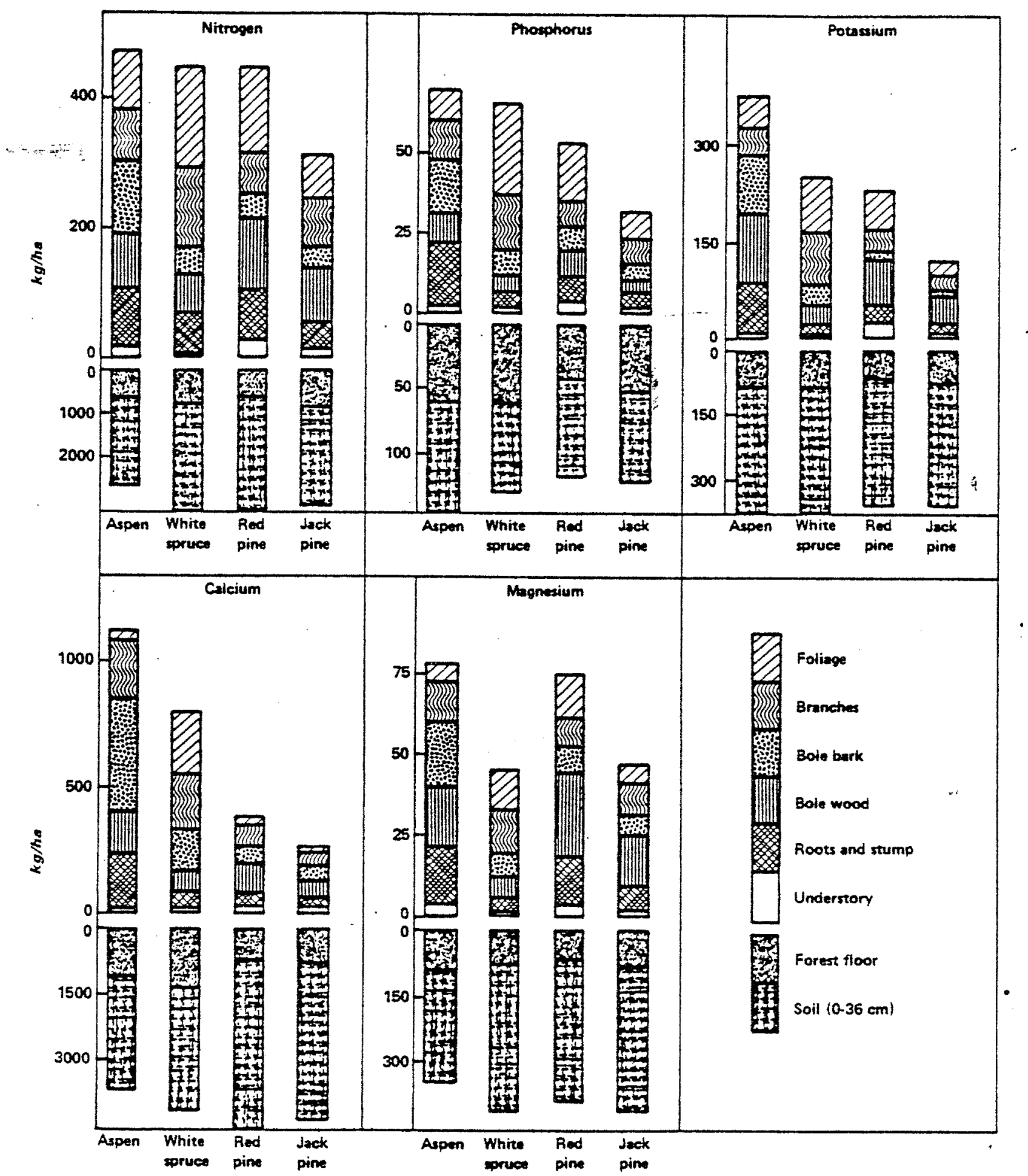

Frg. 2 Nutrient distribution in vegetation and soils.

the removal of this vegetation has resulted in re- and New Zealand the second rotation of Pinus duced growth of subsequent forest stands (Rennie 1957), and similar declines are likely in many parts of Africa (Nye and Greenland 1960). In Australia radiata (D. Don) has frequently produced lower yields than the first (Keeves 1966; Whyte 1973), and in some cases this has been shown to be duc 
TABLE 3. Nutrients in total aboveground tree as a percentage of the nutrients in the $0-36 \mathrm{~cm}$ soil layer

\begin{tabular}{llllll}
\hline Element & Aspen & Spruce & Red pine & Jack pine \\
\hline $\mathrm{N}$ & 18 & 15 & 13 & 10 \\
$\mathrm{P}$ & 54 & 84 & 54 & 35 \\
$\mathrm{~K}$ & 98 & 77 & 58 & 35 \\
$\mathrm{Ca}$ & 32 & 26 & 7 & 5 \\
$\mathrm{Mg}$ & 22 & 12 & 18 & 12 \\
\hline
\end{tabular}

with $\mathrm{NH}_{4} \mathrm{OAc}$; and $\mathrm{N}$ represite $\mathrm{H}_{2} \mathrm{SO}_{4} ;$ soil $\mathrm{Ca}, \mathrm{Mg}_{\mathrm{g}}$ and $\mathrm{K}$ are extracted by the Kjeldahi method.

to a nitrogen deficiency (Stone and Will 1965). In addition, the commonly increased growth response of trees to nutrient additions suggests that many sites are somewhat deficient in certain nutrients even before harvesting (Tennessee Valley Authority 1968). And the incidence of serious nutrient depletion can management to increase as more intensive forest nings, shorer removes more nutrients through thinutilization.

Two comor alteration when not known are (1) to relat measurements are levels to nutrients removed, present soil nutrient forest nutrients removed, or (2) to compare crops that need added with the nutrient uptake of

The percentage of each nutrients to maintain yields. would be removed in an mineral soil nutrient that is shown in Table 3 . The aboveground tree harvest is the $0-36 \mathrm{~cm}$ depth; the used in this calculation $36 \mathrm{~cm}$ is excluded because mineral soil deeper than roots below this depth. The af the small number of the soil are not absolute entities buts of nutrients in with time. For example, soil $\mathrm{N}$ can can be altered fixation (Bartholomew and $N$ can be increased by nutrient levels can be changed if 1965) and other as $\mathrm{pH}$ are altered (Pearsoned if soil conditions such nutrient levels may aiso change if tree nutrient uptake is greater than the replenishment ability of the soil (Heiberg et al. 1959). The data of Table 3 are still useful for comparing species and soils, however. The species differences are clear; jack pine removed the smallest percentage of nutrients and aspen the largest. Nutrient differences are also apparent; much larger percentages of $P$ and $K$ are removed than any other nutrient. This would indicate a potential for deficiencies of these nutrients, but from less soluble on the rate of $P$ and $K$ released of nutrient solubilization in the soil. Our knowledge ited, which makes it diffites in forest soils is limnificance of nutrient difficult to interpret the sig-

Average annual removal from a site.

overstories are much lower, except for nutrient accumulations of agricultural $\mathrm{Ca}$, than the forest nurseries (Table 4). It should bral crops or the high yieids maintained by adding nultural crops can, only be have shown that if nutritrients. Long-term studies of wheat or com stabilizes aren't added, the yield acte ( 1 bushel per acre $=36.37$ bushels per (Miller and Hudelson 1921; Rus $\mathrm{dm}^{3} / 0.405 \mathrm{ha}$ ) sity of Mlinois 1960). 1921; Russell 1961; Univervalues in Table 4 are adjusted to corresp uptake long-term, no-nutrient-addition to correspond to a the aspen trees in the current system, we find that more $\mathrm{Ca}$, about the sament study are taking up as much $\mathrm{N}$ and $\mathrm{Mg}$, and amount of $\mathrm{K}$, about half agricultural crops. The most fertile as much $P$ as the used for agriculture, which leaves the pore usually for forests. A total or aboveground tree harvesting system drains the site of nutrients, particularly Ca. pean forest trees and the large $\mathrm{Ca}$ uptake by EuroEngland, removal of soil Ca that on calluna soils of resulted in lessened soil $\mathrm{Ca}$ by Pinus sylvestris ( $\mathrm{L}$.) Whether the removal of gutre growth.

\begin{tabular}{|c|c|c|c|c|c|c|c|c|}
\hline \multirow{2}{*}{ Species } & \multirow[b]{2}{*}{ Age } & \multirow{2}{*}{$\begin{array}{c}\text { Site } \\
\text { qualitya }\end{array}$} & \multicolumn{5}{|c|}{ Element } & \multirow[b]{2}{*}{ Reference } \\
\hline & & & $N$ & $P$ & $K$ & $\mathrm{Ca}$ & $\mathrm{Mg}$ & \\
\hline $\begin{array}{l}\text { Aspen } \\
\text { White spruce } \\
\text { Red pine } \\
\text { Jack pine } \\
\text { Aspen } \\
\text { Jack pine } \\
\text { Tree nursery } \\
\text { Wheat (grain) } \\
\text { Corn (grain) }\end{array}$ & $\begin{array}{l}40 \\
40 \\
40 \\
40 \\
47 \\
30 \\
1-3 \\
1 \\
1\end{array}$ & $\begin{array}{l}22.9 \\
18.3 \\
20.7 \\
21.3 \\
22.9 \\
18.3-19.8 \\
\overline{40} \\
150\end{array}$ & $\begin{array}{c}9.2 \\
9.6 \\
8.6 \\
6.5 \\
4.4 \\
6.5 \\
50.0 \\
50 \\
135 \\
\end{array}$ & $\begin{array}{l}1.2 \\
1.4 \\
1.0 \\
0.6 \\
0.5 \\
0.5 \\
0.7 \\
11 \\
23 \\
\end{array}$ & $\begin{array}{r}7.2 \\
5.7 \\
4.4 \\
2.4 \\
2.3 \\
3.2 \\
25.0 \\
13 \\
33 \\
\end{array}$ & $\begin{array}{r}21.4 \\
18.0 \\
7.3 \\
5.0 \\
9.4 \\
4.2 \\
15.0 \\
1 \\
16\end{array}$ & $\begin{array}{l}1.4 \\
1.0 \\
1.4 \\
0.9 \\
0.9 \\
0.7 \\
\frac{6}{20}\end{array}$ & $\begin{array}{l}\text { This study } \\
\text { This study } \\
\text { This study } \\
\text { This study } \\
\text { Boyle and Ek } 1972 \\
\text { Morrison } 1973 \\
\text { Stoeckeler and Arneman } 1960 \\
\text { Foth and Turk } 1972 \\
\text { Foth and Turk } 1972\end{array}$ \\
\hline
\end{tabular}


TABLE 5. Forest ecosystem nutrient inputs by atmospheric deposition and outflows by leaching (in kilograms per hectare per year)

\begin{tabular}{|c|c|c|c|c|c|c|}
\hline \multirow{2}{*}{ Element } & \multicolumn{2}{|c|}{ Washington ${ }^{a}$} & \multicolumn{2}{|c|}{$\begin{array}{c}\text { New } \\
\text { Hampshireb }\end{array}$} & \multicolumn{2}{|c|}{ Minnesotac } \\
\hline & Input & Outflow & Input & Outflow & Input & Outfiow \\
\hline $\begin{array}{l}N \\
P \\
K \\
\mathrm{Ca} \\
\mathrm{Mg}\end{array}$ & $\begin{array}{l}1.1 \\
- \\
0.8 \\
2.8 \\
-\end{array}$ & $\begin{array}{l}0.6 \\
1.0 \\
4.5 \\
-\end{array}$ & $\begin{array}{l}7.8 \\
0.1 \\
0.8 \\
3.0 \\
0.8\end{array}$ & $\begin{array}{c}3.0 \\
0.02 \\
2.4 \\
12.2 \\
3.4\end{array}$ & $\begin{array}{l}6.3 \\
0.49 \\
3.9 \\
4.8 \\
1.3\end{array}$ & $\begin{array}{l}2.2 \\
0.26 \\
3.3 \\
6.5 \\
1.9\end{array}$ \\
\hline
\end{tabular}

a Cole ef al. 1967

Likens et al. 1970; Hobbie and Likens 1973.

Tirmmors at al. 1977; Verity and Timmons 1977.

will deplete the soil depends on whether these losses can be balanced by nutrient inputs in precipitation, mineral weathering, and $\mathrm{N}$ fixation. Nutrient inputs by precipitation in temperate regions vary (Weetman and Webber 1972), but are generally of the same magnitude as tree accumulation as shown in Table 4. However, the nutrients in the precipitation that falls outside of the growing season may be lost by leaching. In Washington (Cole et al. 1967), New Hampshire (Likens et al. 1970; Hobbie and Likens 1973), and Minnesota (Timmons et al. 1977; Verry and Timmons 1977) the nutrient input by precipitation and outflow below the rooting zone were measured in mature forest ecosystems (Table 5). More $\mathrm{Ca}$ and $\mathrm{Mg}$ left these systems by leaching than entered by precipitation, whereas the reverse was true for $N$ and $P$ (Table 5). The amount of $N$ lost by denitrification is unknown. Potassium showed a net loss at two sites and a slight gain at one. Part of the leaching losses of the cations are contributed by weathering, which Johnson et al. (1968) have crudely estimated at 8,8 , and $4 \mathrm{~kg} / \mathrm{ha} \mathrm{year}^{-1}$ for $\mathrm{Ca}, \mathrm{Mg}$, and $\mathrm{K}$, respectively. According to longterm soil changes, basic cations are leached from the soil system in temperate zone areas (Simonson 1970). By contrast, the $N$ content may increase markedly due to atmospheric fixation (Nutman 1965; Jensen 1965) and the percentage of $P$ may increase because its rate of leaching is much lower than that of the other constituents.

$\mathrm{Ca}$ appears to be a key nutrient in forest ecosystems because of its large accumulation in comparison with many agricultural crops. Aspen and spruce have more $\mathrm{Ca}$ in their biomass and less in their surface soil than the pines (Table 2). The lower soil $\mathrm{Ca}$ levels under aspen and spruce have resulted in lower $\mathrm{pH}$ values under these species, which can affect reactions occurring in the soil and the avail- ability of certain nutrients. The fact that forest crops take up large amounts of $\mathrm{Ca}$ in relation to agricultural crops suggests that micronutrients need to be examined to see if some of these might also be used in large amounts by forests. Our current knowledge of micronutrient uptake by forests and leveis in forest soils is meager.

Our knowledge of fixation rates, weathering, and mineralization of organic matter in forest ecosystems as well as species nutritional needs is fragmentary, so definite conclusions about the effect of nutrient removal by timber harvesting cannot be made at this time. However, it is clear that the amount and distribution of nutrients that have accumulated in the four species studied are different and that these differences are significant. It is also clear that aboveground tree removal puts a 2- to 11times greater drain on the site (depending on species and nutrient) than if only bole wood is removed. Since the amount of foliage, branches, and bark associated with a given amount of bole wood can be reduced by controlling spacing (Singer and Hutnik 1966; Stiell 1966), it may be possible to reduce nutrient drains without sacrificing yields by the proper adjustment of spacing.

As forests are more intensively cropped for increased yields, nutritional deficiencies are likely to become more common. A great deal of work is needed to quantify the nutrient supplying potential of different sites; then either yields can be increased by fertilization or the yields can be adjusted to balance the natural potential of the site by species selection, degree of utilization, adjustment of rotation length, and other forest management alternatives.

\section{Aclnopledgment}

We appreciate the work of Hardy L. Shirley in establishing the stands used in this study.

Alzison, L. A., W. B. BolLEN, and C. D. Moodre. 1965. Total carbon. In Methods of soil analysis. Part 2. Edited by C. A. Black. Agronomy, 9: 1346-1378.

ART, H. W., and P. L. Marks. 1971. A summary table of biomass and net annual primary production in forest ecosystems of the world. In XV Int. Union For. Res. Organ. Congr. Proc. Forest biomass studies. Edited by H. E. Young. pp. 1-32.

BARTHOLOMEW, W. V., and F. E. ClaRK. (Editors), 1965. Soil nitrogen. Agronomy, 10.

BASKERVILIE, G. L. 1972. Use of logarithmic regression in the estimation of plant biomass. Can. J. For. Res. 2: 4953.

Borre, J. R., and A. R. Ex 1972 An evaluation of some effects of bole and branch pulpwood barvesting on site macronutrients. Can. J. For. Res. 2: 407-412. 
BraY, J. R., and L. A. DudKIEwICZ 1963. The composition. biomass and productivity of two Populus forests. Bull. Torrey Bot. Club, 90: 298-308.

BREMNER, J. M. 1965. Total nitrogen: regular macrokjeldahl method. In Methods of soil analysis. Part 2

Edited by C. A. Black. Agronomy, 9: 1162-1164.

BROADBENT, F. E. 1965. Organic matter. In Methods of soil analysis. Part 2. Edited by C. A. Black. Agronomy, 9: 1397-1400.

Cochran, W. G. 1963. Sampling techniques. 2nd ed. John Wiley and Sons, New York

COle, D. W., S. P. Gessel, and S. F. DiCE. 1967. Distribution and cycling of nitrogen, phosphorus, potassium, and calcium in a second-growth Douglas fir ecosystem. In Primary productivity and mineral cycling in aatural ecosystems. Symp. Proc. Edited by H. E. Young. pp. 198232.

Fork, H. D., and I. M. TURK. 1972. Fundamentals of soil science. Sth ed. John Wiley and Sons, New York

HEIBERG, S. O., L. LEYTON, and H. LoeweNsten. 1959. Influence of potassium fertilizer level on red pine planted at various spacings on a potassium-deficient site. For. Sci.
5: $142-153$.

Hobrie, J. E., and G: E. LIKENs. 1973. Output of phosphorus, dissolved organic carbon, and fine particulate carbon from Hubbard Brook Watersheds. Limnol. Oceanogr. 18: 734-742.

JACKSON, M. L. 1958. Soil chemical analysis. Prentice-Hall, Inc., Englewood Cliffs.

JENSEN, H. L. 1965. Nonsymbiotic nitrogen fixation. In Soil nitrogen. Edited by W. V. Bartbolomew and F. E. Clark. Agronomy, 10: 436-480.

JoHnson, N. M., G. E. LnKeNS, F. H. BORMANN, and R. S. PIERCE. 1968. Rate of chemical weathering of silicate minerals in New Hampshire. Geochim. Cosmochim. Acta, 32: 531-545.

JURGENSEN, M. F, and A. L. LEAF. 1965. Soil moisturefertility interactions related to growth and nutrient uptake of red pine. Soil Sci. Soc. Am. Proc. 29: 294-299.

KEEVES, A. 1966. Some evidence of the loss of productivity with successive rotation in $P$. radiata in southeast of South Australia. Aust. For. 30: $51-63$.

KITTREDGE, J. 1934. Evidence of the rate of forest succession on Star Island, Minnesota. Ecology, 15: 24-35.

LEAF, A. L., R. E. LeONARD, R. F. WrTtweR, D. H. BICXELHAUPT. 1975. Four-year growth response of plantation red pine to potash fertilization and irrigation in New York. For. Sci. 21: 89-96.

LiKens, G. E., F. H. Bormann, N. M. Jornson, D. W. Fisher, and R. S. PIERCE. 1970. Effects of forest cutting and herbicide treatment on nutrient budgets in the Hubbard Brook Watershed ecosystem. Ecol. Monogr. 40: 2347.

LUTZ, H. J., and R. F. ChaNoler, JR. 1946. Forest soils. John Wiley and Sons, New York.

MADGWICK, H. A. I., E. H. WhITE, G. K. XYDIAS, and A. L. LEAF. 1970. Biomass of Pinus resinosa in relation to potas sium nutrition. For. Sci. 16: 154-159.

Miller, M. F., and R. R. Hudelson, 1921. Thirty years of field experiments with crop rotation, manure, and fertilizers. Univ: Mo, Coll. Agric, Agric. Exp. Str, Bull. 182.

MORRISON, I. K. 1973. Distribution of elements in aerial components of several natural jack pine stands in northern Ontario. Can. J. For. Res. 3: 170-179.
NuTMan, P. S. 1965. Symbiotic nitrogen fixation. In Soi\} nitrogen. Edited by W. V. Bartholomew and F. E. Clark. Agronomy, 10: 360-383.

NYE, P. H., and D. J. GreenLAND. 1960. The soil under shifting cultivation. Commonw. Bur. Soils Tech. Commun.

OvingtoN, J. D. 1956. The form, weights and productivity of tree species grown in close stands. New Phytol. 55:
289-304.

1962. Quantitative ecology and the woodland ecosystems concept. Edited by J. B. Cragg. Adv. Ecol. Res. 1: 103-192.

PEARSON, R. W., and F. ADAMS. (Editors). 1967. Soil acidity and liming. Agronomy, 12.

Peterson, E. B., Y. H. Chan, and J. B. Crigg. 1970. Aboveground standing crop, leaf area, and caloric value in an aspen clone near Calgary, Alberta. Can. J. Bot. 48: 14591469.

PoliARD, D. F. W. 1972. Aboveground dry matter production in three stands of trembling aspen. Can. J. For. Res.
2: $27-33$.

RENNIE, P. J. 1955. The uptake of nutrients by mature forest growth. Plant Soil, 7: 49-95. imporance Uptake of nutrients by timber forest and its 51: 101-115.

Russell 115 .

9thed, W. 1961. Soil conditions and plant growtb. 9 th ed. John Wiley and Sons, New York.

SCHLAEGel, B. E. 1975. Yields of four 40-year-old northern conifers and aspen in adjacent stands. Can. J. For. Res. 5 :
$278-280$.

Simonson, R. W. 1970. Loss of nutrient elements during soil formation. In Nutrient mobility in soils: accumulation and losses. Edired by O. P. Engelstad. Soil Sci. Soc. Am. Spec. Publ. 4: 21-45.

Snger, F. P, and R. J. HutnIK. 1966. Accumulation of organic matter in red pine and Norway spruce plantations at various spacings. Penn. State Univ. Res. Briets, 1: 2228.

SOIL SURVEY STAFF. 1975. Soil taxonomy. A basic soil classification for making and interpreting soil surveys. U.S. Dep. Agric. Soil Conserv. Serv. Agric. Handb. 436.

Stiell, W. M. 1966. Red pine crown development in relation to spacing. Can. Dep. For. Publ. No. 1145.

Stoeczeler, J. H., and H. F. ARNeMAN. 1960. Fertilizers in forestry. Adv. Agron. 12: 127-195.

STONE, E. L, and G. M. WILL. 1965. Nitrogen deficiency of second generation radiaza pine in New Zealand. In 2nd N. Am. For. Soils Conf. Proc. Edited by C. T. Youngberg.
pp. 117-139.

TENNESSEE VALLEY AUTHORITY. 1968. Forest fertilizationtheory and practice. Natl. Fert. Dev. Cent., Muscle Sboals,
Alabama.

TIMMONS, D. R., E. S. VERRY, R. E. BURweLL, add R. F. HoLt. 1977. Nutrient transport in surface runoff and interflow from an aspen-birch forest. J. Envüron. Qual. 6: 188-192.

UNIVERSTTY OF ILLINOIS. 1960. The morrow plots. Dep. Agron. Coll. Agric. Circ. 777. (Plus 1965 supplement).

VerRY, E. S., and D. R. TnMmoNs. 1977. Precipitation nutrients in the open and under two forests in Minnesota. Can. J. For. Res. 7: 112-119.

WeEtMAN, G. F, and B. WebBer. 1972. The influence of wood harvesting on the nutrient status of two spruce stands. Can. J. For. Res. 2: 351-369. 
WHYTE, A. G. D. 1973. Productivity of first and second crops of Pinus radiata on the Moutere gravel soils of Nelson. N.Z. J. For. 18: 87-103.

WITTWER, R. F., A. L. LEAF, and D. H. BiCxeLHAUPT. 1975. Biomass and chemical composition of fertilized and/or irrigated Pinus resinose Ait. plantations. Plant Soil, 42: $629=651$.
ZayrrkovskI, J. 1971. Dry weight and leat area of aspen trees in northern Wisconsin. In XV Int. Union For. Res. Organ. Congr. Proc. Forest biomass studies. Edited by H. E. Young. pp. 193-205. 